CASSOWARY volume 2 (1): 01 - 17

ISSN : 2614-8900

E-ISSN : 2622-6545

CProgram Pascasarjana Universitas Papua, https://pasca.unipa.ac.id/

\title{
Persepsi masyarakat terhadap pengelolaan sampah dan kesediaan membayar (willingness to pay) dalam pelayanan pengelolaan sampah di Distrik Manokwari Barat
}

\author{
Grcae Dharmawati Timang, Ihwan Tjoli dan Ludia T. Wambrauw. \\ Pascasarjana Ilmu Lingkungan \\ Universitas Negeri Papua, Manokwari 98314, Indonesia. \\ E-mail : giz_1808@yahoo.co.id
}

\begin{abstract}
This study aims to determine community's perceptions of waste management, determine the value of Willingness to Pay (WTP) and analyze the household characteristics $(\mathrm{X})$, which as the perception of waste management $\left(\mathrm{X}_{1}\right)$, income $\left(\mathrm{X}_{2}\right)$, family number $\left(\mathrm{X}_{3}\right)$ and education level $\left(\mathrm{X}_{4}\right)$. These factors are expected to affect the amount of the WTP value. The study was conducted in the District of Manokwari Barat approximately two months (May to June 2016). Total of 60 respondents distributed in 6 villages. Most of the respondents said (55\%) that the dustman activities done quite well. However, the placement of the container is limited only in the activity center. The majority respondents (61.67\%) only use plastic bags for garbage container. The cost of taking out the trash is Rp. $5000 \mathrm{~s} / \mathrm{d}$ Rp. 20,000, and the weekly cost they spend Rp. $10.000 \mathrm{~s} / \mathrm{d}$ Rp. 60,000 . The majority respondents $(80 \%)$ stated that the garbage collecting process has done fairly well, the dustman collecting garbage every day with limited fleet and funds. The majority of respondents $(56.67 \%)$ said the process of garbage removal and transport has done fairly well, well (21.67\%), and unfavorable (21.67\%). The majority respondents $(61.67 \%)$ said that the implementation of the landfill were done well, rubbish was dumped without any treatment. This research result that the WTP group of Rp. 50,000 / month was $60 \%$, the Group of WTP Rp. 75,000 / month was 6.67\%, and Group WTP Rp. 100,000 / month was 33.33\%. Potential retribution Rp. 1.258.563.333 / month. Based on the multiple regression analysis that the entire household characteristics significantly affect the value of WTP, which the value of $\mathrm{R}_{2}$ was 0,513 . The coefficient value of each variables to the WTP were $\mathrm{X}_{1}(-14,046.268), \mathrm{X}_{2}(0.005), \mathrm{X}_{3}(-6,882.381)$, and $\mathrm{X}_{4}(9,813.867)$. The F-test was resulted that $\mathrm{F}_{\text {count }}$ at 14.478 higher than $\mathrm{F}_{\text {table }}$ at 2.54 , this mean that all variables simultaneously throughout the study variables significantly influence the public decision give WTP values (Y). Similar results were on the t-test results, partially any study variables significantly influence the decision of the community provides WTP values (Y). The $t_{\text {count }}$ was $\mathrm{X}_{1}(-2.897), \mathrm{X}_{2}(2.605), \mathrm{X}_{3}(-2.260)$, and $\mathrm{X}_{4}(2.646)$ higher than $\mathrm{t}_{\text {table }}$ at 1.673.
\end{abstract}

Keyword: Perception, Waste management perception and Willingness to Pay (WTP).

\section{PENDAHULUAN}

Sampah merupakan salah satu isu penting yangharus dihadapi lingkungan perkotaan sejalan dengan perkembangan jumlah penduduk dan peningkatan aktivitas pembangunan. Pertumbuhan dan perkembangan sebuah kota selalu diiringi pertambahan jumlah penduduk 
yang cepat. Pertambahan jumlah penduduk akan mendorong meningkatnya konsumsi barang dan jasa yang pada akhirnya akan berimplikasi pada jumlah sampah yang dihasilkan.

Pengelolaan sampah di Indonesia umumnya masih dilakukan dengan menggunakan metode pengumpulan, pengangkutan ke TPS dan pemusnahan sampah di Tempat Pembuangan Akhir (TPA). Dimana pengelolaan sampah sangat tergantung pada armada pengangkutan.

Komponen pokok sistem pengelolaan persampahan menurut Damanhuri (1993) dibagi menjadi 5 (lima) komponen yang saling mendukung yaitu teknis operasional, pembiayaan, organisasi dan manajemen, peraturan (hukum/legalitas) dan peran serta masyarakat. Dari kelima komponen tersebut, komponen pembiayaan merupakan salah satu komponen terpenting dalam pengelolaan sampah yang dapat mempengaruhi komponen yang lainnya.

Faktor yang mempengaruhi belum dilakukannya pengelolaan sampah secara terpadu di Manokwari diantaranya adalah jumlah armada sampah yang beroperasi belum mencukupi, tidak adanya program pelatihan untuk meningkatkan kualitas aparat pengelola sampah dan upah aparat pengelola sampah yang masih rendah.

Pembiayaan kegiatan pengolahan sampah di Kabupaten Manokwari selama ini dilakuakan melalui APBD (Anggaran Pendapatan dan Belanja Daerah) dan retribusi yang dipungut dari masyarakat yang dimaksudkan untuk mendukung kegiatan pengolahan sampah. Akan tetapi dalam penentuan tarif retribusi tersebut masyarakat sebagai obyek yang terkena dampak kebijakan belum dimintai pendapatnya.

Penelitian ini bertujuan untuk 1) mengetahui persepsi masyarakat mengenai pengelolaan sampah yang dilakukan pemerintah Kabupaten Manokwari saat ini, 2) mengetahui kesediaan membayar masyarakat dalam hal ini rumah tangga di Distrik Manokwari Barat dalam pengelolaan sampah, 3) menganalisis faktorfaktor yang diduga mempengaruhi besaran nilai kesedian masyarakat membayar mengenai pengelolaan sampah yang terdiri dari faktor tingkat pendidikan, jenis pekerjaan, tingkat pendapatan dan jumlah tanggungan keluarga.

\section{METODE PENELITIAN}

Penelitian dilakukan di Distrik Manokwari Barat Kabupaten Manokwari selama kurang lebih dua bulan yaitu pada bulan Mei s/d Juni 2016. Badan Pusat Statistik (2015) menyebutkan, bahwa Distrik Manokwari Barat adalah distrik yang mempunyai jumlah pendu-duk tertinggi di Kabupaten Manokwari yaitu 88.198 jiwa $(55,03 \%)$ dengan jumlah rumah tangga sebanyak 18.833 rumah tangga.

Variabel-variabel yang digunakan dalam penelitian ini terbagi menjadi dua yaitu :

1. Variabel terikat (dependent variable) yaitu nilai Willingness to Pay (WTP) masyarakat untuk pengelolaan sampah yang lebih baik di Kabupatean Manokwari.

2. Variabel bebas (independent variable) meliputi : persepsi responden terhadap pengelolaan sampah $\left(\mathrm{X}_{1}\right)$, tingkat pendapatan $\left(\mathrm{X}_{2}\right)$, jumlah tanggungan keluarga $\left(\mathrm{X}_{3}\right)$ dan tingkat pendidikan $\left(\mathrm{X}_{4}\right)$. 


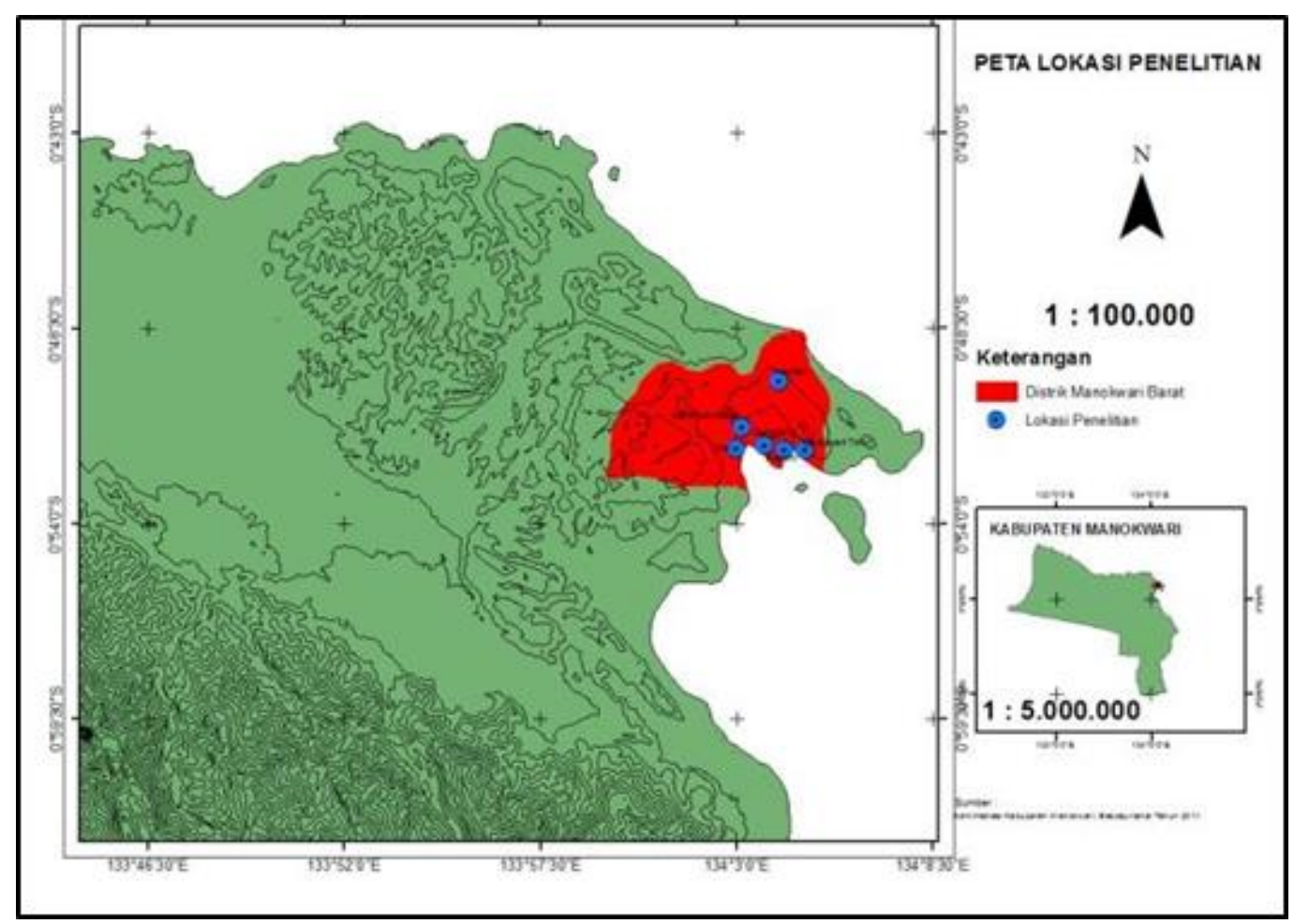

Gambar 1. Peta Lokasi Penelitian

Secara operasional variabel yang ada dalam penelitian ini dapat didefinisikan sebagai berikut :

\section{Besaran Nilai Willingness to Pay (Y)}

Besaran nilai kesediaan membayar rumah tangga untuk peningkatan pengelolaan sampah di Kota Manokwari yang diukur dalam Rupiah. Responden diberikan tiga alternatif nilai, yaitu $\mathrm{Rp}$ 50.000,00; Rp 75.000,00; Rp 100.000,00.

\section{Persepsi pengelolaan sampah $\left(\mathrm{X}_{1}\right)$}

Penilaian menyeluruh atas pengelolaan sampah yang dilakukan Pemerintah Kabupaten Manokwari saat ini, dibedakan menjadi baik, sedang dan buruk.

Tabel 1. Kriteria dan Skor Penilaian Willingness to Pay

\begin{tabular}{cll}
\hline No. & Indikator & Kriteria \\
\hline 1. & Nilai WTP Rp. 100.000/bulan & Tinggi \\
2. & Nilai WTP Rp. 75.000/bulan & Sedang \\
3. & Nilai WTP Rp. 50.000/bulan & Rendah \\
\hline
\end{tabular}

Sumber : Skala Likert (Sugiyono, 2014) dimodifikasi

Tabel 2. Kriteria dan Skor Persepsi Responden Mengenai Pengelolaan Sampah.

\begin{tabular}{clc}
\hline Kriteria & \multicolumn{1}{c}{ Indikator } & \multicolumn{1}{c}{ Skor } \\
\hline Baik & $\begin{array}{l}\text { Terdapat }>2 \text { (dua) tahap pengelolaan sampah yang telah } \\
\text { dilakukan dengan baik }\end{array}$ & $9,35-12,00$ \\
Cukup & $\begin{array}{l}\text { Terdapat 2 (dua) dua tahap pengelolaan sampah yang telah } \\
\text { dilakukan dengan baik }\end{array}$ & $6,68-9,34$ \\
Kurang & $\begin{array}{l}\text { Terdapat }<2 \text { (dua) tahap pengelolaan sampah yang telah } \\
\text { dilakukan dengan baik }\end{array}$ & 4,00-6,67 \\
\hline
\end{tabular}




\section{Tingkat pendapatan $\left(\mathbf{X}_{2}\right)$}

Pendapatan rumah tangga secara keseluruhan baik pendapatan yang bersumber dari kepala keluarga maupun anggota keluarga lain yang juga bekerja namun masih tinggal dalam satu atap. Variabel diukur dalam satuan rupiah (Rp)(Tabel 3).

\section{Jumlah Tanggungan Keluarga $\left(\mathbf{X}_{3}\right)$}

Jumlah atau banyaknya orang yang tinggal satu atap dalam sebuah rumah dan menjadi tanggungan kepala keluarga. Jumlah anggota keluarga ditunjukkan dengan satuan jiwa (Tabel 4).

\section{Tingkat Pendidikan $\left(\mathbf{X}_{4}\right)$}

Tingkat pendidikan formal yang telah dicapai responden yang dibagi ke dalam empat tingkatan pendidikan dengan satuan adalah tahun (Tabel 5).

Jumlah populasi dalam penelitian ini yaitu 18.418 rumah tangga yang tercatat berdomisili di Distrik Manokwari Barat (Badan Pusat Statistik, 2015). Penentuan jumlah sampel didasarkan pada metode Roscoe, dimana penetuan jumlah sampel didasarkan pada jumlah variabel penelitian (independen dan dependen) yaitu minimal 10 kali jumlah variabel yang diteliti dengan pengambilan sampel dari populasi dilakukan secara proporsional berdasarkan jenis pekerjaan di setiap kelurahan (Sugiyono, 2009).

Tabel 3. Kriteria dan Skor Penilaian Tingkat Pendapatan

\begin{tabular}{clc}
\hline No & \multicolumn{1}{c}{ Indikator } & Kriteria \\
\hline 1. & Lebih kecil Rp, 2.237.000 / bulan & Kurang Mampu \\
2. & Rp. 2.237.000 - Rp. 4.474.000 / bulan & Menengah \\
3. & 2 X UMR = Rp. 4.474.000 / bulan & Mampu \\
\hline
\end{tabular}

Sumber : Badan Pusat Statistik, 2016 (dimodifikasi)

Tabel 4. Kriteria dan Kode Jumlah Tanggungan Keluarga

\begin{tabular}{clc}
\hline Jumlah & \multicolumn{1}{c}{ Jiwa Kriteria } & Kode \\
\hline$>5$ & jiwa Keluarga besar & 3 \\
5 jiwa & Keluarga sedang & 2 \\
$<5$ jiwa & Keluarga kecil & 1 \\
\hline
\end{tabular}

Sumber: Hasan, 1986.

Tabel 5. Kriteria dan Skor Tingkat Pendidikan

\begin{tabular}{lccc}
\hline \multicolumn{1}{c}{ Tingkat Pendidikan } & Tahun & Kriteria & Skor \\
Formal & & & 4 \\
Perguruan Tinggi & $>12$ & Tinggi & 3 \\
SLTA & $10-12$ & Sedang & 2 \\
SD dan SLTP & $1-9$ & Rendah & 1 \\
Tidak sekolah & 0 & Sangat rendah & \\
\hline
\end{tabular}

Sumber : Seoharjo dan Patong, 1991. 
Tabel 6. Jumlah Sampel Penelitian

\begin{tabular}{|c|c|c|c|c|c|c|c|}
\hline \multirow[t]{2}{*}{ No. } & \multirow[t]{2}{*}{$\begin{array}{c}\text { Kelurahan / } \\
\text { Kampung }\end{array}$} & \multirow[t]{2}{*}{$\begin{array}{c}\text { Jumlah Rumah } \\
\text { Tangga }\end{array}$} & \multirow[t]{2}{*}{ Jumlah Sampel } & \multicolumn{4}{|c|}{$\begin{array}{c}\text { Jumlah Sampel } \\
\text { berdasarkan Jenis } \\
\text { Pekerjaan }\end{array}$} \\
\hline & & & & 1 & 2 & 3 & 4 \\
\hline 1. & Wosi & 5498 & 18 & 5 & 4 & 4 & 5 \\
\hline 2. & Manokwari Barat & 4417 & 14 & 4 & 3 & 4 & 3 \\
\hline 3. & Amban & 2847 & 9 & 2 & 3 & 2 & 2 \\
\hline 4. & Sanggeng & 2147 & 7 & 1 & 2 & 2 & 2 \\
\hline 5. & Padarni & 1829 & 6 & 1 & 2 & 2 & 1 \\
\hline 6. & Manokwari Timur & 1567 & 6 & 2 & 1 & 1 & 2 \\
\hline 7. & Inggramui & 52 & 0 & 0 & 0 & 0 & 0 \\
\hline 8. & Udopi & 43 & 0 & 0 & 0 & 0 & 0 \\
\hline 9. & Tanah Merah Indah & 11 & 0 & 0 & 0 & 0 & 0 \\
\hline 10. & Soribo & 7 & 0 & 0 & 0 & 0 & 0 \\
\hline & Jumlah & 18.418 & 60 & 15 & 15 & 15 & 15 \\
\hline
\end{tabular}

Sumber : Badan Pusat Statistik, 2015 diolah.

Keterangan :

1. PNS/TNI/POLRI

2. Karyawan swasta

3. Karyawan niaga / buruh harian lepas

4. Wiraswasta

Metode pengumpulan data yang digunakan adalah wawancara menggunakan kuesioner dan studi kepustakaan. Data yang digunakan terbagi atas dua jenis, yaitu data primer data sekunder. Data primer diperoleh secara langsung melalui wawancara dan pengamatan langsung di lapangan. Data sekunder diperoleh dari Dinas Pekerjaan Umum Kabupaten Manokwari, BPS Manokwari, internet, serta berbagai literatur baik buku maupun jurnal - jurnal yang relevan.

Analisis data dibagi menjadi 2 yaitu analisis kualitatif dan analisis kuantitatif. Analisis kualitatif dilakukan dengan menggunakan analisis deskriptif, sedangkan analisis kuantitatif digunakan untuk mengetahui faktor-faktor yang berpengaruh terhadap willingness to pay.
Analisis Willingness To Pay Metode Contingent Valuation Method (CVM)

Pelaksanaan CVM menggunakan pendekatan Hanley dan Splash (1993), adalah sebagai berikut:

1. Membangun Pasar Hipotetis (Setting up The Hypothetical Market)

Seluruh responden diberi informasi bahwa demi meningkatkan kualitas pengelolaan sampah dan mengurangi produksi sampah yang dihasilkan, pemerintah berencana untuk meningkatkan pelayanan pengelolaan sampah yang lebih baik mulai dari pewadahan sampah hingga pembuangan akhir sampah. Namun permasalahan muncul karena pemerintah tidak memiliki cukup biaya dalam pengelolaan sampah, peralatan, dan perlengkapannya tersebut serta sarana penunjang lainnya. Oleh karena itu, masyarakat yang nantinya akan menikmati pengelolaan sampah tersebut ikut bertanggung jawab dalam hal pembiayaan dalam hal pemeliharaannya peralatan dan perlengkapannya serta sarana penunjang 
dengan memberikan pembayaran atau retribusi tiap kepala keluarga setiap bulan.

\section{Mendapatkan Nilai WTP}

Teknik yang digunakan dalam penelitian adalah dichotomous choice yaitu menawarkan responden jumlah uang tertentu dan menanyakan apakah responden mau membayar atau tidak sejumlah uang tersebut untuk memperoleh peningkatan kualitas pelayanan pengelolaan sampah.

3. Menghitung Dugaan Rata-Rata Nilai WTP (Estimating Mean (EWTP)

EWTP diduga dengan menggunakan nilai rata-rata dari penjumlahan keseluruhan nilai WTP dibagi dengan jumlah responden. Dugaan Rata-rata WTP dihitung dengan rumus :

$$
E W T P=\frac{\sum_{i=1}^{n} W i}{n}
$$

Dimana :

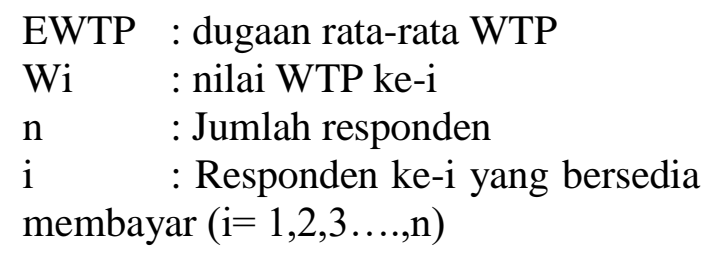

\section{Menjumlahkan Data (Aggregating} Data)

Penjumlahan data merupakan proses dimana nilai rata-rata WTP dikonversikan terhadap total populasi yang dimaksud. Setelah menduga nilai ratarata WTP maka dapat diduga nilai total WTP dari masyarakat dengan menggunakan rumus :

$$
\text { TWTP }=\sum_{i=1}^{n} W T P i n i
$$

Dimana :

TWTP : total WTP

WTPi : WTP individu sampel ke-i

$\begin{aligned} \mathrm{Ni} & \text { jumlah sampel ke-i yang } \\ & \text { bersedia membayar sebesar } \\ & \text { WTP } \\ & \text { : } \\ & \text { responden ke-i yang bersedia } \\ & \text { membayar }(\mathrm{i}=1,2,3 \ldots, \mathrm{n})\end{aligned}$

Metode analisis yang digunakan untuk menganalisis faktor-faktor yang mempengaruhi besaran nilai WTP menggunakan analisis regresi linear berganda. Data diolah dengan program SPSS (Statistical Product and Service Solutions). Analisis regresi linier berganda digunakan untuk melihat hubungan antara Willingness to Pay (Y) dengan karakteristik rumah tangga responden yang meliputi persepsi pengelolaan sampah $\left(\mathrm{X}_{1}\right)$, tingkat pendapatan $\left(\mathrm{X}_{2}\right)$, jumlah tanggungan keluarga $\left(\mathrm{X}_{3}\right)$ dan tingkat pendidikan $\left(\mathrm{X}_{4}\right)$. Persamaan matematika dari analisis regresi linier berganda adalah sebagai berikut (Sugiyono, 2009)

$$
Y=a+b_{1} X_{1}+b_{2} X_{2}+b_{3} X_{3}+b_{4} X_{4}
$$

dimana :

$$
\begin{aligned}
\mathrm{Y}= & \text { Willingness to Pay } \\
\mathrm{a} & \text { Konstanta (nilai Y apabila nilai } \\
& \left.\mathrm{X}_{1}, \mathrm{X}_{2}, \ldots . . \mathrm{X}_{\mathrm{n}}=0\right) \\
\mathrm{b}_{1-5}= & \text { Koefisien regresi } \\
\mathrm{X}_{1}= & \text { Persepsi responden mengenai } \\
& \text { pengelolaan sampah saat ini } \\
\mathrm{X}_{2}= & \text { Tingkat pendapatan } \\
\mathrm{X}_{3}= & \text { Jumlah tanggungan keluarga } \\
\mathrm{X}_{4}= & \text { Tingkat pendidikan }
\end{aligned}
$$

Uji $F$ dilakukan untuk mengetahui pengaruh karakteristik rumah tangga responden (X) yang meliputi persepsi responden mengenai pengelolaan sampah saat ini (X1), tingkat pendapatan (X2), jumlah tanggungan keluarga (X3) dan tingkat pendidikan (X4) secara bersama-sama (simultan) terhadap Willingness to Pay (Y), dengan persamaan sebagai berikut (Sugiyono, 2009) : 


$$
F=\frac{R^{2}(N-m-1)}{m\left(1-R^{2}\right)}
$$

dimana :

$\mathrm{F} \quad=$ nila Fhitung

$\mathrm{R}^{2} \quad=$ koefisien determinasi

$\mathrm{N}=$ total jumlah sampel

$\mathrm{M} \quad=$ jumlah prediktor

Jika nilai Fhitung > F tabel, maka semua variabel bebas secara bersamasama berpengaruh signifikan terhadap variabel terikat.

Bila nilai Fhitung < F tabel, maka semua variabel bebas secara bersamasama tidak berpengaruh signifikan terhadap variabel terikat.

Selanjutnya, Uji t digunakan untuk mengetahui seberapa besar pengaruh karakteristik rumah tangga $(X)$ secara individual (parsial) yang terdiri dari persepsi responden mengenai pengelolaan sampah saat ini $\left(\mathrm{X}_{1}\right)$, tingkat pendapatan $\left(\mathrm{X}_{2}\right)$, jumlah tanggungan keluarga $\left(\mathrm{X}_{3}\right)$ dan tingkat pendidikan $\left(\mathrm{X}_{4}\right)$ mempengaruhi Willingness to Pay (Y). Persamaan yang digunakan (Sugiyono, 2009):

$$
t=\frac{b}{S^{b}}
$$

dimana :

$\mathrm{t}=$ nila Thitung

$\mathrm{b}=$ nilai parameter

$\mathrm{Sb}=$ standart error dari $\mathrm{b}$

Jika nilai Thitung $>\mathrm{T}$ tabel, maka terdapat pengaruh signifikan terhadap variabel terikat.

Bila nilai Thitung < T tabel, maka tidak terapat pengaruh terhadap variabel terikat.

\section{HASIL DAN PEMBAHASAN}

\section{Identitas responden}

\section{Umur}

Hurlock (1994) menyebutkan bahwa tingkatan usia manusia dibagi menjadi tiga kategori yaitu usia muda (< 30 tahun), usia dewasa (30 tahun sampai dengan 50 tahun), dan usia tua (> 50 tahun). Mayoritas penduduk yang berdomisili di Distrik Manokwari Barat tergolong dalam tingkatan usia dewasa yaitu sebanyak 47 responden, kategori usia tua sebanyak 4 responden dan responden dengan kategori usia muda sebanyak 9 responden (Gambar 1).

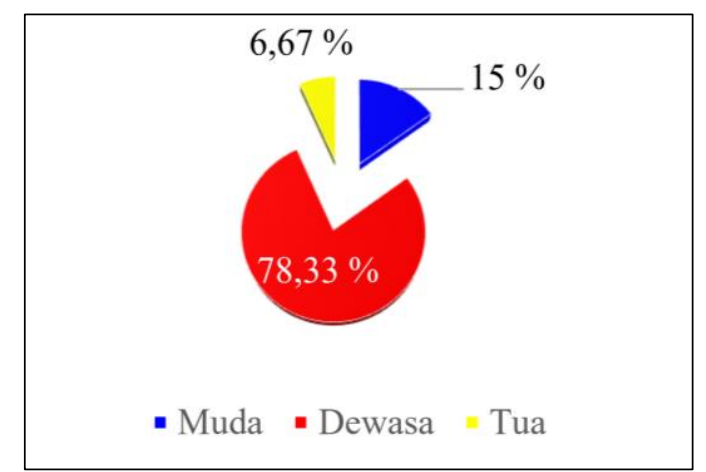

Gambar 1. Persentase penduduk berdasarkan umur

\section{Pendidikan Formal}

Karakteristik responden berdasarkan tingkat pendidikan formal disajikan pada Gambar 2.

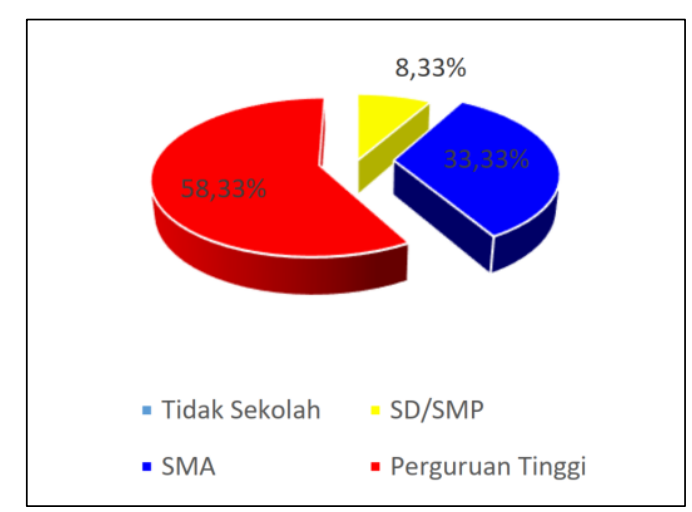

Gambar 2. Persentase penduduk berdasarkan pendidikan formal 
Gambar 5.2 di atas memperlihatkan bahwa sebagian besar $(58,33 \%)$ penduduk di Distrik Manokwari Barat memiliki tingkat pendidikan hingga ke perguruan tinggi (tinggi). Tingkat pendidikan tertinggi kedua adalah SMA dan pendidikan terendah penduduk di Distrik Manokwari Barat adalah tingkat SD/SMP. Gambar 2 di atas juga memperlihatkan bahwa di Distrik Manokwari Barat tidak terdapat penduduk yang buta huruf atau tidak pernah mengenyam bangku sekolah.

\section{Pendapatan}

Sebagian besar $(48,33 \%)$ masyarakat di Distrik Manokwari Barat memiliki pendapatan lebih kecil Rp. 2.237.000,- / bulan atau tergolong kurang mampu, masyarakat yang berpenghasilan antara Rp. 2.237.000 - Rp. 4.474.000/ bulan atau golongan mampu adalah sebanyak $40 \%$. Sebagian kecil $(11,67$ $\%)$ masya-rakat memiliki tingkat pendapatanlebih besar dari Rp. 4.474.000 / bulan atau tergolong mampu.

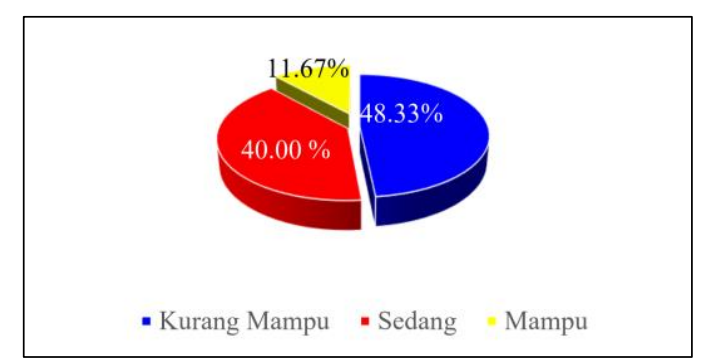

Gambar 3. Persentase responden berdasarkan pekerjaan

\section{Jumlah Anggota Keluarga}

Jumlah tanggungan keluarga merupakan anggota keluarga yang hidup dalam satu rumah, termasuk didalamnya suami/istri, anak-anak dan anggota keluarga lainnya ataupun bukan keluarga yang menjadi tanggungan (jumlah jiwa). Sebagian besar $(36,67 \%)$ penduduk memiliki jumlah anggota keluarga lebih besar dari 5 jiwa. Masyarakat yang memiliki anggota keluarga kurang dari 5 jiwa sebesar $30 \%$. Masyarakat yang memiliki anggota keluarga 5 jiwa adalah sebanyak $33,33 \%$.

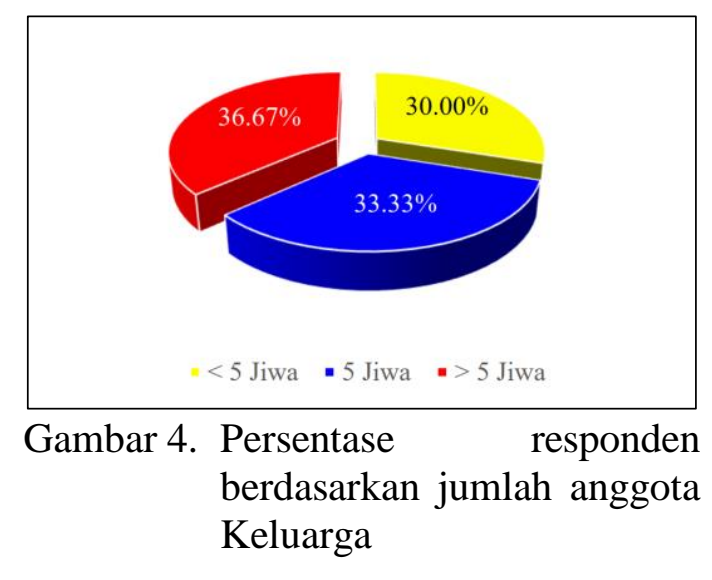

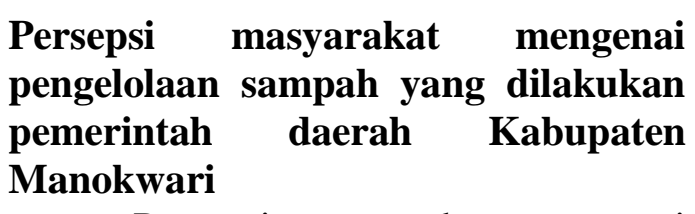

Persepsi masyarakat mengenai pengelolaan sampah yang selama ini dilakukan Pemerintah Daerah Kabupaten Manokwari di Distrik Manokwari Barat, diperoleh melalui jawaban responden terhadap empat aspek pengelolaan sampah. Aspek tersebut meliputi : pewadahan, pengumpulan, pemindahan dan pengangkutan, serta pembuangan akhir sampah.

Menurut masyarakat, dari empat item pengelolaan sampah dua item sudah dilakukan dengan cukup baik. Item tersebut adalah pengumpulan sampah $(80,00 \%)$ dan pemindahan serta pengangkutan sampah $(56,67 \%)$. Sedangkan pewadahan sampah $(55 \%)$ dan pembuangan akhir $(61,67 \%)$ menu-rut persepsi masyarakat masih dilakukan kurang baik. 
Tabel 7. Persepsi Masyarakat Mengenai Pengelolaan Sampah yang dilakukan Pemerintah Daerah Kabupaten Manokwari

\begin{tabular}{|c|c|c|c|c|}
\hline No & Pengelolaan sampah & Kriteria & $\begin{array}{c}\text { Responden } \\
\text { Jumlah }\end{array}$ & Nisbah $(\%)$ \\
\hline \multirow[t]{3}{*}{1} & Pewadahan & Baik & 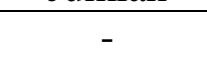 & - \\
\hline & & Cukup baik & 27 & 45,00 \\
\hline & & Kurang baik & 33 & 55,00 \\
\hline \multirow[t]{3}{*}{2} & Pengumpulan & Baik & - & - \\
\hline & & Cukup baik & 48 & 80,00 \\
\hline & & Kurang baik & 12 & 20,00 \\
\hline \multirow[t]{3}{*}{3} & Pemindahan dan Pengangkutan & Baik & 13 & 21,67 \\
\hline & & Cukup baik & 34 & 56,67 \\
\hline & & Kurang baik & 13 & 21,67 \\
\hline \multirow[t]{3}{*}{4} & Pembuangan akhir & Baik & 4 & 6,67 \\
\hline & & Cukup baik & 19 & 31,67 \\
\hline & & Kurang baik & 37 & 61,67 \\
\hline
\end{tabular}

Meskipun demikian, persepsi masyarakat cukup baik mengenai pengelolaan sampah tidak sesuai dengan kenyataan. Dimana, sampah sangat mudah kita jumpai berhamburan hampir di seluruh titik-titik tertentu di luar jalanjalan protokol, kontainer-kontainer penampung sampah sementara di Pasar Sanggeng dan Pasar Wosi sampah masih sering menumpuk. Selain itu, tumpukantumpukan sampah juga mudah kita jumpai di sekitaran jalan utama di Distrik Manokwari Barat misalnya di Jalan Swaven Perkebunan dan di depan Pertamina Jalan Trikora Wosi. Hal ini diduga karena penyebaran jumlah sampel yang digunakan dalam penelitian berdasarkan jumlah penduduk di setiap kampung/kelurahan, sehingga sebagian besar sampel terpusat di Kelurahan Wosi (30 \%) dan Kelurahan Manokwari Barat $(23,3 \%)$. Kedua kelurahan tersebut merupakan keluarahan yang selama ini mendapatkan pelayanan truk-truk sampah, sehingga memunculkan persepsi responden yang baik. Di sisi lain, jumlah sampel untuk Kelurahan Amban (15\%), Kelurahan Sanggeng (11,7 \%), Kelurahan Padarni dan Manokwari Timur masing-masing hanya $10 \%$, ke empat kelurahan tersebut merupakan kelurahan yang kurang atau bahkan tidak mendapatkan pelayanan truk sampah. Meskipun persepsi responden kurang baik, akan tetapi secara rataan seluruh responden tertutup oleh persepsi yang cukup baik yang berasal dari Kelurahan Wosi dan Kelurahan Manokwari Barat.

\section{Pewadahan Sampah}

Sebagian besar (55\%) masyarakat berpendapat, bahwa kegiatan pewadahan sampah yang dilakukan dalam proses pengelolaan sampah di Distrik Manokwari Barat dilakukan kurang baik. Suharso (2013) menyatakan, bahwa proses pewadahan sampah di Distrik Manokwari Barat telah dilakukan dengan cukup baik. Proses pewadahan sampah dilakukan menggunakan kontainer sebagai Tempat Pembuangan Sementara (TPS), kontainer ini memiliki dimensi panjang $330 \mathrm{~cm}$, lebar $180 \mathrm{~cm}$ dan tinggi $120 \mathrm{~cm}$ dengan kapasitas $6 \mathrm{~m} 3$ sampah. Kontainer yang digunakan sebagai wadah sampah (TPS) telah memenuhi standar SNI 19-2454-2002. Meskipun demikian, wadah kontainer yang disediakan oleh Pemerintah di Distrik Manokwari Barat terbatas hanya pada lokasi-lokasi tertentu dan jumlahnya masih sangat terbatas. Kontainer sampah 
umumnya hanya di tempatkan di pusatpusat keramaian seperti di Pasar Wosi dan Pasar Sanggeng serta belum tersebar secara merata untuk melayani kawasan perumahan masyarakat. Selain itu kontainer yang digunakan sebagai wadah sampah seluruhnya menimbulkan bau yang disebabkan oleh keterlambatan proses pengangkutan sampah.

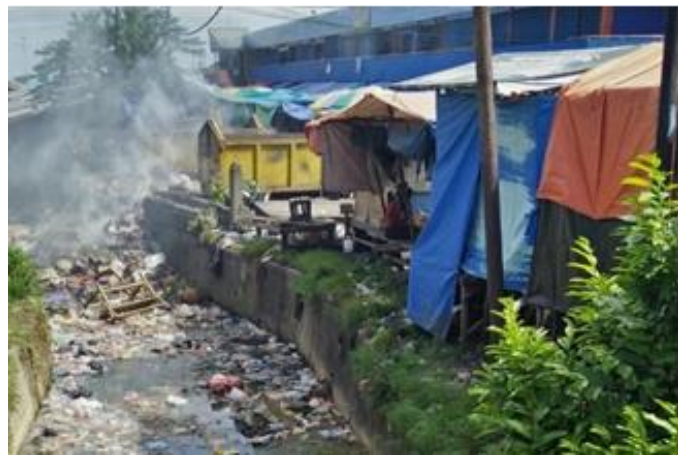

Gambar 5. Kontainer Sampah di Pasar Sanggeng (23 Januari 2017)

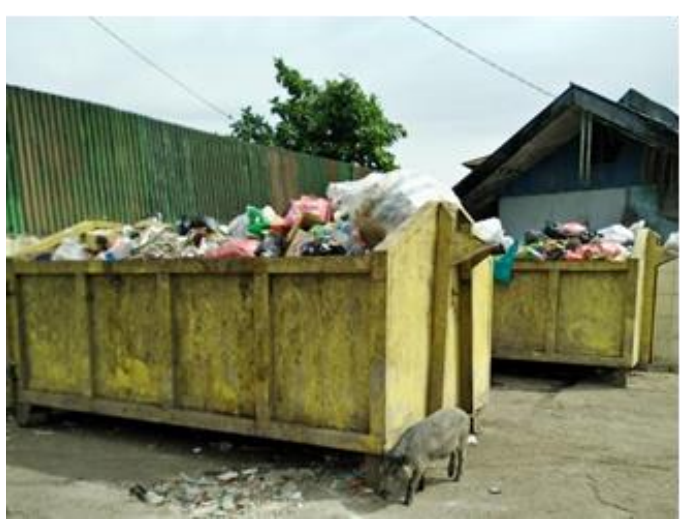

Gambar 6. Kontainer Sampah di Pasar Wosi (24 Januari 2017)

Sebagian besar $(61,67 \%)$ masyarakat hanya menggunakan kantong plastik untuk wadah sampah yang mereka hasilkan kemudian membawanya ke kontainer-kontainer sampah yang tersedia di Pasar Wosi dan Pasar Sanggeng dengan membayarkan sejumlah uang. Harga yang harus mereka bayarkan untuk sekali membuang sampah pun bervariasi mulai dari Rp. 5.000 - Rp. 20.000, ratarata dalam seminggu mereka akan membuang sampah ke kontainer-kontainer tersebut $2-3$ kali, artinya dalam seminggu mereka harus mengeluarkan sejumlah uang mulai dari Rp. $10.000-$ Rp. 60.000 untuk membuang sampah mereka.

\section{Pengumpulan sampah}

Mayoritas masyarakat $(80,00 \%)$ menyatakan bahwa proses pengumpulan sampah yang dilakukan oleh Pemerintah Daerah di Distrik Manokwari Barat telah dilakukan cukup baik, sedangkan yang lainnya $(20,00 \%)$ menyatakan bahwa proses pengumpulan sampah dilakukan kurang baik. Hasil penelitian ini sejalan dengan hasil penelitian Suharso (2013), dimana sebagian besar $(66,7 \%)$ masyarakat menyatakan bahwa pengelolaan sampah khususnya proses pengumpulan sampah telah dilakukan dengan cukup baik. Menurut masyarakat yang menyatakan proses pengumpulan sampah telah dilakukan dengan cukup baik, dikarenakan petugas sampah setiap hari melakukan pengumpulan sampah meskipun memiliki keterbatasan jumlah armada dan dana. Meskipun demikian, terdapat $20,00 \%$ masyarakat yang mengemukakan bahwa pengumpulan sampah belum dilakukan dengan baik dan teratur sehingga sampah cepat menumpuk.

\section{Pemindahan dan pengangkutan sampah}

Sebagian besar $(56,67 \%)$ masyarakat menyatakan bahwa proses pemindahan dan pengangkutan sampah telah dilakukan dengan cukup baik, baik $(21,67 \%)$ dan kurang baik $(21,67 \%)$. Hasil penelitian ini sejalan dengan hasil penelitian Suharso (2013) yang menyatakan bahwa pengangkutan dan pemindahan sampah di Distrik Manokwari Barat telah dilakukan dengan cukup baik. Petugas sampah cukup rajin dalam mengangkut dan memindahkan sampah, dalam sehari setidaknya dua kali petugas 
sampah tersebut keliling kota untuk memindahkan dan mengangkut sampah.

\section{Pembuangan akhir sampah}

Sebagian besar $(61,67 \%)$ masyarakat menyatakan bahwa pelaksanaan pembuangan akhir sampah di Distrik Manokwari Barat dilakukan kurang baik. Hal ini dikarenakan seringnya terjadi pemalangan di TPA Sowi terkait dengan hak ulayat masyarakat. Pemalangan ini berdampak secara langsung dengan menghambat kelancaran pengangkutan sampah ke TPA sehingga terjadi penumpukan sampah.

Menurut Kepala Bidang Pemukiman dan Penyehatan Lingkungan (P2L) yang selama ini melakukan pengelolaan sampah melalui Seksi Penyehatan Lingkungan Dinas Pekerjaan Umum Kabupaten Manokwari. Anggaran pengelolaan sampah yang dialokasikan Pemerintah Kabupaten Manokwari sebesar Rp. 1.691.800.000 untuk tahun 2016 belum cukup untuk melayani seluruh masyarakat dalam pengelolaan sampah di Kabupaten Manokwari. Alokasi dana tersebut hanya cukup untuk melayani pengangkutan sampah dari TPS ke TPA setiap hari dan pengelolaan sampah (pemadatan) di TPA.

Perbaikan pengelolaan sampah di Kabupaten Manokwari hingga saat ini hanya terlihat dari peningkatan intensitas pengangkutan sampah dari TPS di seputaran Pasar Sanggeng dan Pasar Wosi yang rutin diangkat setiap hari. Meskipun demikian, pengelolaan sampah masih sebatas pada memindahkan sampah dari sumber penghasil sampah ke TPA. Di TPA sampah selanjutnya dimusnahkan dengan menggunakan metode sanitary landfill. Fakta di lapangan, sampah hanya dibuang di TPA tanpa perlakuan sama sekali sehingga mengakibatkan penumpukan.

\section{Kesediaan Membayar Masyarakat dalam hal ini Rumah Tangga di Dis- trik Manokwari Barat dalam Penge- lolaan Sampah}

Rata-rata Willingness To Pay

(WTP) tiap kelompok dan rata-rata WTP keseluruhan rumah tangga di Distrik Manokwari Barat dalam pengelolaan sampah disajikan pada Tabel 8.

Tabel 8. Distribusi nilai WTP

\begin{tabular}{ccccc}
\hline No & Kelompok WTP & $\begin{array}{c}\text { Jumlah Responden } \\
\text { (Rumah Tangga) }\end{array}$ & Persentase (\%) & $\begin{array}{c}\text { WTP x Jumlah } \\
\text { Responden (Rp) }\end{array}$ \\
\hline 1 & 50000 & 36 & 60,00 & 1.800 .000 \\
2 & 75000 & 4 & 6,67 & 300.000 \\
3 & 100000 & 20 & 33,33 & 2.000 .000 \\
\hline & Total & 60 & 100,00 & 4.100 .000 \\
\hline & EWTP (WTP Rataan) & & 68.333 \\
\hline
\end{tabular}

Tabel 8 di atas memperlihatkan bahwa nilai WTP kelompok masyarakat yang bersedia membayar sebesar Rp. 50.000 / bulan untuk pengelolaan sampah adalah sebesar 60,00 \%, nilai WTP kelompok masyarakat yang bersedia Distrik Manokwari Barat berkisar antara Rp. 50.000 sampai dengan Rp. 100.000 / bulan / rumah tangga.
Hasil perhitungan nilai total WTP adalah sebesar Rp 1.258.563.333,-- per bulan (Tabel 9). Nilai ini menunjukkan nilai dugaan rata-rata WTP dari total populasi rumah tangga yang ada di Distrik Manokwari Barat sebesar 18.418 rumah tangga menurut BPS Manokwari tahun 2015. 
Tabel 9. Total WTP (TWTP)

\begin{tabular}{cccccc}
\hline No & Kelompok WTP & $\begin{array}{c}\text { Jumlah } \\
\text { Responden } \\
(\text { Rumah } \\
\text { Tangga) }\end{array}$ & $\begin{array}{c}\text { Persentase } \\
(\%)\end{array}$ & $\begin{array}{c}\text { Populasi } \\
\text { (Rumah } \\
\text { Tangga) }\end{array}$ & TWTP/Bulan \\
\hline 1 & 50.000 & 36 & 60,00 & 11,051 & 552.540 .000 \\
2 & 75.000 & 4 & 6,67 & 1,228 & 92.090 .000 \\
3 & 100.000 & 20 & 33,33 & 6,139 & 613.933 .333 \\
\hline \multicolumn{2}{c}{ Total } & 60 & 100,00 & 18.418 & 1.258 .563 .333 \\
\hline
\end{tabular}

Tabel 9 di atas memperlihatkan bahwa dengan tiga nilai kelompok WTP yang diperoleh dari rumah tangga di Distrik Manokwari Barat, maka nilai total WTP yang akan diperoleh pada pilihan nilai WTP kelompok masyarakat yang bersedia membayar sebesar Rp. 50.000 / bulan untuk pengelolaan sampah adalah sebesar Rp. 552.540.000/ bulan (60\%), nilai WTP kelompok masyarakat yang bersedia membayar Rp. 75.000 / bulan adalah sebesar Rp. 92.090.000 $(6,67 \%)$ dan nilai kelompok 100.000 / bulan adalah sebesar Rp. 613.933.333 $(33,33 \%)$.

Peran serta masyarakat khususnya aspek pembiayaan melalui retribusi dapat dijadikan membayar Rp. 75.000 / bulan adalah 6,67 \% dan nilai kelompok masyarakat yang bersedia membayar sebesar Rp. 100.000 / bulan adalah sebesar 33,33 \%. Hasil ini memperlihatkan bahwa rata-rata nilai WTP yang bersedia masyarakat bayarkan untuk pengelolaan sampah di Distrik Manokwari Barat adalah sebesar Rp. 68.333 / bulan / rumah tangga. Hasil penelitian ini memperlihatkan, bahwa kesedian masyarakat membayar untuk pengelolaan sampah di alternatif Pemerintah Daerah Kabupaten Manokwari dalam meningkatkan pelayanan pengelolaan sampah. Hasil penelitian ini, menegaskan bahwa masyarakat di Distrik Manokwari Barat tidak keberatan berkontribusi dalam membayar retribusi pengelolaan sampah. Nilai retribusi yang bersedia dikeluarkan berkisar antara Rp. 50.000 s/d Rp. 100.000 / bulan / keluarga. Jika seluruh rumah tangga dibebankan retribusi sebesar Rp. 50.000 / bulan dan Rp. 75.000 s/d Rp. 100.000 khusus untuk usaha dan bisnis, maka akan diperoleh potensi Pendapatan Asli Daerah (PAD) sebesar Rp. 1.258.563.333, / bulan atau sebesar Rp.15.102.760.000/tahun khusus dari Distrik Manokwari Barat.

Melihat besarnya nilai potensi PAD tersebut atau $893 \%$ lebih tinggi jika dibandingkan alokasi pengelolaan sampah tahun anggaran 2016, maka pengelolaan sampah yang lebih baik dan kesejahteraan petugas-petugas pengangkut sampah yang merupakan ujung tombak pengelolaan sampah untuk mendapatkan gaji yang layak akan terpenuhi.

\section{Analisis faktor-faktor yang mempe- ngaruhi nilai WTP}

Hasil analisis nilai total WTP diperoleh nilai R2 sebesar 0,513. Nilai tersebut dapat diartikan bahwa keragaman WTP dapat dijelaskan oleh model sebesar 51,30 \% sedangkan 48,70\% sisanya dijelaskan oleh variabel di luar model. Nilai Korelasi Ganda (R) sebesar 0,716 menjelaskan, bahwa terjadi hubungan yang kuat (Sugiyono, 2009) antara karakteristik rumah tangga responden (X) yang meliputi : persepsi responden mengenai pengelolaan sampah saat ini $\left(\mathrm{X}_{1}\right)$, tingkat pendapatan $\left(\mathrm{X}_{2}\right)$, jumlah tanggungan keluarga $\left(\mathrm{X}_{3}\right)$ dan tingkat pendidikan $\left(\mathrm{X}_{4}\right)$ terhadap keputusan 
masyarakat di Distrik Manokwari Barat dalam memberikan nilai Willingness to Pay (Y). Tabel 10 di bawah ini memperlihatkan, bahwa seluruh variabel yang digunakan dalam penelitian signifikan mempengaruhi model.

Tabel 10. Hasil analisis nilai WTP

\begin{tabular}{lllll}
\hline No & Variabel & Koefisien & Sig & Kesimpulan \\
\hline 1. & Persepsi Pengelolaan Sampah $\left(\mathrm{X}_{1}\right)$ & $-14.046,268$ & 0,005 & Signifikan \\
2. & Tingkat Pendapatan $\left(\mathrm{X}_{2}\right)$ & 0,005 & 0,012 & Signifikan \\
3. & Jumlah Tanggungan Keluarga $\left(\mathrm{X}_{3}\right)$ & $-6.882,381$ & 0,028 & Signifikan \\
4. & Tingkat Pendidikan $\left(\mathrm{X}_{4}\right)$ & $9.813,867$ & 0,011 & Signifikan \\
\hline
\end{tabular}

$\mathrm{R}=0,716 \mathrm{R}-\mathrm{Sq}=51,30 \% \mathrm{R}-\mathrm{Sq}(\operatorname{adj})=47,70 \%$

Model regresi linear berganda yang diperoleh

adalah sebagai berikut :

$$
\begin{aligned}
\mathrm{WTP}= & 53.552,218-14.046,268 \mathrm{X} 1+ \\
& 0,005 \mathrm{X} 2-6.882,381 \mathrm{X} 3+ \\
& 9.813,867 \mathrm{X} 4+\varepsilon
\end{aligned}
$$

Dimana :

$$
\begin{array}{ll}
\text { WTP } & =\text { Williningnes to pay } \\
\mathrm{X}_{1} & =\text { Persepsi Pengelolaan sampah } \\
\mathrm{X}_{2} & =\text { Pendapatan } \\
\mathrm{X}_{3} & =\text { Tanggungan keluarga } \\
\mathrm{X}_{4} & =\text { Pendidikan }
\end{array}
$$

Nilai koefisien bertanda negatif pada variabel persepsi mengenai pengelolaan sampah dengan nilai 14.046,268 berarti bahwa setiap kenaikan persepsi mengenai pengelolaan sampah yang lebih baik maka nilai WTP yang diberikan akan menurun sebesar 14.046,268 rupiah. Hal ini dikarenakan semakin baik persepsi masyarakat terhadap pengelolaan sampah, maka ke-mampuan pemerintah daerah dalam mengelola sampah akan semakin baik, sehingga nilai yang rendah mengindikasikan bawa pemerintah daerah secara finansial tidak mampu melakukan penge-lolaan sampah. Oleh sebab itu, maka masyarakat akan meningkatkan nilai kesedian membayar untuk membantu peme-rintah melakukan pengelolaan sampah yang lebih baik. Sebaliknya, semakin baik persepsi pengelolaan sampah maka akan semakin menurun nilai kesedian masyarakat membayar pengelolaan sampah.

Tingkat Pendapatan $\left(\mathrm{X}_{2}\right)$ merupakan salah satu variabel ekonomi yang memiliki keeratan dengan kemampuan ekonomi masyarakat dalam membayar biaya retribusi sampah. Semakin tinggi pendapatan seseorang maka semakin besar nilai WTP yang akan dibayarkan. Hasil penelitian ini dipreoleh nilai koefisien tingkat pendapatan adalah positif 0,005, dimana setiap kenaikan tingkat pendapatan sebesar satu rupiah maka nilai WTP yang diberikan akan meningkat sebesar 0,005 rupiah. Hasil penelitian ini sesuai dengan Simanjuntak (2009) dan Herdiani (2009) yang menjelaskan, bahwa semakin tinggi pendapatan maka semakin tinggi kemampuan ekonomi seseorang, sehingga semakin tinggi kemampuan dan kesempatan individu tersebut untuk dapat dan bersedia membayar biaya pengelolaan sampah.

Nilai koefisien bertanda negatif pada variable tanggungan keluarga $\left(\mathrm{X}_{3}\right)$ dengan nilai sebesar 6.882,381, diartikan bahwa setiap kenaikan jumlahkeluarga satu jiwa maka nilai WTP yang diberikan masyarakat akan turun sebesar 6.882,381 rupiah. Hasil penelitian menjelaskan, bahwa jumlah tanggungan keluarga berkaitan dengan banyaknya pengeluaran yang akan dikeluarkan oleh keluarga. Semakin banyak jumlah keluarga maka semakin meningkat pengeluaran keluarga tersebut, sehingga jumlah tanggu- 
ngan keluarga berpengaruh negatif terhadap kesediaan membayar. Menurut masyarakat di Distrik Manokwari Barat, jumlah tanggungan keluarga akan memberikan dampak menurunkan kemampuan masyarakat dalam memberikan nilai WTP. Hal ini dikarenakan, masyarakat akan lebih mendahulukan kebutuhan biaya sekolah anak-anak mereka dan biaya kesehatan dibandingkan meningkatkan biaya retribusi sampah.

Nilai koefisien bertanda positif pada variable pendidikan dengan nilai 9.813,867 berarti bahwa setiap peningkatan satu tahun pendidikan maka nilai WTP yang diberikan akan meningkat sebesar 9.813,867 rupiah. Hasil penelitian memperlihatkan, bahwa tingkat pendidikan sangat mempengaruhi pola pikir masyarakat terhadap pengelolaan sampah. Masyarakat dengan tingkat pendidikan lebih baik cenderung lebih memahami bagaimana sulit dan mahalnya pengelolaan sampah. Masyarakat dengan pendidikan lebih tinggi cenderung memiliki $\mathrm{WTP}=53.552,218-$ $14.046,268 \mathrm{X} 1+0,005 \mathrm{X} 2-6.882,381 \mathrm{X} 3$ $+9.813,867 \mathrm{X} 4+\varepsilon$ kemampuan membayar lebih baik. Selain itu, semakin tinggi tingkat pendidikan seseorang, maka pemikiran wawasan serta pandanganya akan semakin luas sehingga dapat berfikir lebih cepat. Tingkat pendidikan juga akan mempengaruhi penilaian seseorang terhadap masalah sampah dan lingkungan, sehingga berpengarh terhadap nilai WTP.

\section{Pengaruh Secara Simultan}

Uji $F$ dilakukan untuk mengetahui pengaruh persepsi masyarakat mengenai pengelolaan sampah saat ini $\left(\mathrm{X}_{1}\right)$, tingkat pendapatan $\left(\mathrm{X}_{2}\right)$, jumlah tanggungan keluarga $\left(\mathrm{X}_{3}\right)$ dan tingkat pendidikan $\left(\mathrm{X}_{4}\right)$ secara bersama-sama (simultan) terhadap Willingness to Pay (Y). Hal ini dijelaskan melalui nilai Fhitung sebesar 14,478 yang lebih besar dari nilai Ftabel sebesar 2,54. Hasil penelitian ini menjelaskan bahwa seluruh variabel bebas yang digunakan dalam penelitian ini saling terkait satu dengan yang lainnya secara bersama-sama berpengaruh signifikan terhadap keputusan masyarakat memberikan nilai WTP.

\section{Pengaruh Secara Parsial}

Pengujian ini bertujuan untuk melihat kebermaknaan (signifikansi) pengaruh variabel bebas $\left(\mathrm{X}_{1}, \mathrm{X}_{2}, \mathrm{X}_{3}\right.$, dan $\left.\mathrm{X}_{4}\right)$ secara parsial terhadap variabel terikat (Y).

Tabel 11 memperlihatkan bahwa masing- masing variabel karakteristik rumah tangga $(\mathrm{X})$ yang meliputi : persepsi responden mengenai pengelolaan sampah $\left(\mathrm{X}_{1}\right)$, tingkat pendapatan $\left(\mathrm{X}_{2}\right)$, jumlah tanggungan keluarga $\left(\mathrm{X}_{3}\right)$ dan tingkat pendidikan $\left(\mathrm{X}_{4}\right)$ secara parsial siginifikan mempengaruhi keputusan masyarakat memberikan nilai Willingness to Pay (Y) dengan nilai thitung setiap variabel lebih besar dari nilai ttabel.

Tabel 11. Hasil Uji Koefisien Regresi Parsial (Uji t)

\begin{tabular}{clccl}
\hline No & Variabel & $\mathrm{t}_{\text {hitung }}$ & $\mathrm{t}_{(55 ; 0,05)}$ & Kesimpulan \\
\hline 1. & Persepsi Pengelolaan Sampah $\left(\mathrm{X}_{1}\right)$ & -2.897 & 1,673 & Signifikan \\
2. & Tingkat Pendapatan $\left(\mathrm{X}_{2}\right)$ & 2.605 & 1,673 & Signifikan \\
3. & Jumlah Tanggungan Keluarga $\left(\mathrm{X}_{3}\right)$ & -2.260 & 1,673 & Signifikan \\
4. & Tingkat Pendidikan $\left(\mathrm{X}_{4}\right)$ & 2.646 & 1,673 & Signifikan \\
\hline
\end{tabular}


Persepsi pengelolaan sampah $\left(\mathrm{X}_{1}\right)$ secara parsial mempengaruhi keputusan masyarakat dalam memiliki persepsi yang baik mengenai pengelolaan sampah cenderung semakin besar berpeluang untuk bersedia membayar lebih tinggi untuk upaya pengelolaan sampah yang lebih baik.

Hal serupa juga berlaku untuk variabel Tingkat Pendapatan $\left(\mathrm{X}_{2}\right)$ yang secara parsial signifikan mempengaruhi nilai Willingness to Pay (Y). Hal ini disebabkan dengan pendapatan yang tinggi maka rumah tangga memiliki dana lebih yang dapat dialokasikan untuk membayar retribusi pengelolaan sampah. Irawan (2009), menjelaskan bahwa kemampuan individu dalam mengkonsumsi sebuah barang dipengaruhi oleh pendapatannya. Lebih lanjut Simanjuntak (2009) menerangkan, bahwa tingkat pendapatan masyarakat sangat berpengaruh terhadap besarnya nilai WTP yang ingin dibayarkan oleh masyarakat untuk iuran kebersihan atau pengelolaan sampah. Hal ini erat kaitannya dengan kemampuan ekonomi masyarakat dalam membayar biaya pelayanan pengelolaan sampah yang diperolehnya. Dimana, semakin tinggi pendapatan masyarakat maka semakin besar pula nilai WTP yang akan dibayarkan.

Hasil penelitian ini memperlihatkan, bahwa variabel Jumlah Tanggungan Keluarga $\left(\mathrm{X}_{3}\right)$ secara parsial signifikan mempengaruhi nilai Willingness to Pay (Y). Hal ini dikarenakan pertambahan jiwa pada suatu rumah tangga akan memberikan dampak pada kenaikan biaya kebutuhan keluarga sehingga alokasi dana yang digunakan untuk retribusi pengelolaan sampah akan dikurangi. Soeharjo dan Patong (1991) menjelaskan, bahwa kebutuhan keluarga dipengaruhi oleh jumlah anggota keluarga, sehingga dapat dikatakan bahwa semakin besar jumlah memberikan nilai Willingness to Pay (Y). Hasil penelitian ini menjelaskan, bahwa persepsi masyarakat mengenai pengelolaan sampah yang lebih baik diartikan dengan kemampuan keuangan Pemerintah Daerah yang mencukupi, sehingga dana yang dialokasikan oleh keluarga atau rumah tangga untuk pengelolaan sampah akan dikurangi dan dialihkan untuk kebutuhan yang lainnya. Meskipun demikan, hasil penelitian ini berbeda dengan hasil penelitian Amanda (2013), dimana seseorang yang anggota keluarga/tanggungan keluarga, maka semakin besar pula biaya yang akan dikeluarkan oleh keluarga tersebut dalam usaha pemenuhan kebutuhan.

Tingkat Pendidikan $\left(\mathrm{X}_{4}\right)$ secara signifikan mempengaruhi nilai Willingness to Pay (Y), hal ini dikarenakan tingkat pendidikan berpengaruh terhadap pengetahuan seseorang. Semakin tinggi tingkat pendidikan, maka pengetahuannya akan semakin baik terhadap bagaimana rumit dan mahalnya biaya pengelolaan sampah. Menurut Mo shler (1991), bahwa tingkat pendidikan yang baik akan membuat seseorang berfikir secara baik dan rasional terhadap sesuatu yang dilakukan. Pendidikan akan membuat seseorang lebih mampu dan berani dalam mengambil keputusan tepat dari berbagai alternatif yang ada. Dalam kasus ini, tingkat pendidikan yang lebih baik membuat seseorang berfikir secara rasional mengenai pengelolaan sampah, sehingga keputusan yang lebih berani dan lebih tepat untuk meningkatkan nilai WTP akan cenderung dilakukan dalam pengelolaan sampah.

\section{KESIMPULAN DAN SARAN Kesimpulan}

1. Persepsi masyarakat terhadap pengelolaan dibedakan berdasarkan empat aspek sebagai berikut :

a) Sebagian besar (55\%) masyarakat memiliki persepsi bahwa pewadahan sampah masih dilakukan kurang baik, hanya 
sebesar $45 \%$ masyarakat yang memiliki persepsi pewadahan telah dilakukan cukup baik.

b) Mayoritas (80\%) masyarakat memiliki persepsi pengumpulan sampah sudah dilakukan dengan cukup baik, sedangkasn 20\% masyarakat memiliki persepsi kurang baik trhadap pngumpulan sampah.

c) Sebagian besar $(56,67 \%)$ masyarakat memiliki persepsi pemindahn dan pengangkutan sampah dilakukan cukup baik, sedangkan yang memiliki persepsi baik dan kurang baik masing-masing sebesar 21,67\%.

d) Sebagian besar $(61,67 \%)$ masyarakat memiliki persepsi pembuangan akhir sampah dilakukan kurang baik, cukup baik sebesar $31,67 \%$ dan baik sebesar $6,67 \%$.

2. Nilai WTP kelompok masyarakat yang bersedia membayar sebesar Rp.50.000/bulan adalah sebesar Rp. $552.540 .000 /$ bulan $(60,00 \%)$, nilai WTP kelompok masyarakat yang bersedia membayar Rp. 75.000 /bulan adalah sebesar Rp.92.090.000 $(6,67 \%)$ dan nilai kelompok masyarakat yang bersedia membayar sebesar Rp.100.000/ bulan adalah sebesar Rp. 613.933.333 (33,33\%). Potensi Pendapatan Asli Daerah (PAD) dari retribusi sampah adalah Rp.1.258.563.333/bulan atau sebesar Rp.15.102.760.000 / tahun khusus untuk DistrikManokwari Barat.

3. Seluruh variabel penelitian terdiri dari persepsi terhadap pengelolaan sampah $\left(\mathrm{X}_{1}\right)$, tingkat pendapatan $\left(\mathrm{X}_{2}\right)$, jumlah tanggungan keluarga $\left(\mathrm{X}_{3}\right)$ dan tingkat pendidikan $\left(\mathrm{X}_{4}\right)$ secara nyata mempengaruhi besaran nilai kesediaan masyarakat membayar retribusi pengelolaan sampah.

\section{Saran}

1. Pemerintah Kabupaten Manokwari diharapkan dapat menerapkan retribusi pengelolaan sampah berdasarkan hasil nilai WTP dalam penelitian ini. Hasil penelitian ini dapat digunakan sebagai dasar dalam menetapkan nilai retribusi pengelolaan sampah di Kabupaten Manokwari. Potensi retribusi melalui nilai WTP penelitian ini adalah sebesar Rp.1.258.563.333/bulan terdiri dari Rp.552.540.000/bulan untuk kelompok WTP Rp. 50.000/ bulan, Rp.92.090.000/ bulan untuk kelompok WTP Rp. 75.000/bulan dan Rp. 613.933. 333/ bulan untuk kelompok WTP Rp.100.000/bulan. Meskipun demikian, penerapan retribusi selayaknya juga memperhatikan daerah yang hingga saat ini belum mendapatkan layanan pengelolaan sampah.

2. Melibatkan masyarakat dalam pengelolaan sampah dapat dilakukan pada aspek pembiayaan melalui retribusi. Penerapan nilai retribusi sesuai dengan hasil nilai WTP pada penelitian ini, dapat dijadikan pilihan Pemerintah Daerah Kabupaten Manokwari untuk mengatasi permasalahan sampah yang dihadapi saat ini.

3. Penelitian lanjutan khususnya dalam hal perhitungan kebutuhan armada termasuk biaya pemeliharaan dalam hal pengelolaan sampah perlu dilakukan agar pelayanaan pengelolaan sampah di Kabupaten Manokwari dapat dilakukan secara tepat dan efisien. 
DAFTAR PUSTAKA

Amanda, K. 2013. Persepsi Akuntan dan Mahasiswa Akuntansi Terhadap Etika Profesi Dipandang dari Segi Gender dan Level Hierarki. Universitas Pendidikan Ganesha. Bali.

Badan Pusat Statistik. 2016. Kabupaten Manokwari Dalam Angka 2016. Badan Pusat Statistik Kabupaten Manokwari. Manokwari.

Badan Pusat Statistik. 2015. Distrik Manokwari Barat Dalam Angka 2015. Badan Pusat Statistik Kabupaten Manokwari. Manokwari.

Damanhuri, T.P. 1993. Pengelolaan Lindi di TPA Sampah Dalam Kaitannya Dengan Pencegahan Pencemaran Lingkungan, http://hmtl.itb.ac.id/wordpress/ wp-content/uploads/2011/03/Bag 7P-PenangananLindi.pdf (12 Mei 2015).

Hanley, N. D. dan C. L. Splash. 1993. Cost-Benefit Analysis and the Environment. Edward Elgar. London.

Hasan, S.F. 1986. Alam Pikiran AlGazali Mengenai

Pendidikan dan Ilmu. Diponegoro. Bandung.

Hurlock, E.B. 1994. Psikologi Perkembangan, Suatu Pendekatan Sepanjang Rentang Kehidupan. Erlangga. Jakarta.

Irawan, H. 2009. 10 Prinsip Kepuasan Pelanggan. PT. Elex Media Komputindo. Jakarta.

Ladyance, S. dan L. Yuliana. 2014. Variabel- Variabel Yang Mepengaruhi Kesediaan Membayar (Willingness To Pay) Masyarakat Bidaracina Jatinegara Jakarta Timur. Jurnal Ilmiah WIDYA, 2, 41-47.
Mosher, A.T. 1991. Menggerakkan dan Membangun Pertanian. CV. Yasaguna. Jakarta.

Simanjuntak, G. E. M. 2009. Analisis Willingness To Pay Masyarakat terhadap peningkatan pelayanan system penyediaan Air Bersih dengan WSLC (Water Sanitation for Low Income) (Studi kasus desa situdaun, Kabupaten Bogor). Institut Pertanian Bogor. Bogor.

Sugiyono. 2009. Statistik Untuk Penelitian. Penerbit Alfabet. Bandung.

Suharso. 2013. Pengelolaan Sampah dan Faktor- Faktor yang Mempengaruhinya di Distrik Manokwari Barat Kabupaten Manokwari. Tesis, Program Pascasarjana UNIPA. Manokwari.

Soeharjo, A. dan D. Patong. 1991. SendiSendi Pokok Ilmu Usahatani. Universitas Hasanudin. Ujung Pandang.

Sugiyono. 2014. Statistik Untuk Penelitian. Penerbit Alfabeta. Bandung. 